University of Wollongong

Research Online

Australian Institute for Innovative Materials -

Papers

Australian Institute for Innovative Materials

$1-1-2018$

Barium- and Strontium-Containing Anode Materials toward Ceria-Based Solid Oxide Fuel Cells with High Open Circuit Voltages

\author{
Zheng Gong \\ University of Science and Technology of China \\ Wenping Sun \\ University of Wollongong, wenping@uow.edu.au \\ Zongzi Jin \\ University of Science and Technology of China \\ Lina Miao \\ University of Science and Technology of China \\ Wei Liu \\ University of Science and Technology of China, Chinese Academy of Sciences, wliu@ustc.edu.cn
}

Follow this and additional works at: https://ro.uow.edu.au/aiimpapers

Part of the Engineering Commons, and the Physical Sciences and Mathematics Commons

Research Online is the open access institutional repository for the University of Wollongong. For further information contact the UOW Library: research-pubs@uow.edu.au 


\title{
Barium- and Strontium-Containing Anode Materials toward Ceria-Based Solid Oxide Fuel Cells with High Open Circuit Voltages
}

\begin{abstract}
Developing ceria-based solid oxide fuel cells (SOFCs) with low cost, high power density, and, in particular, high working efficiency is of great significance to practical applications. In this work, Ba- and Srcontaining composites ( $\mathrm{Ni}-\mathrm{Ba}_{1-\mathrm{x}} \mathrm{Sr}_{\mathrm{x}} \mathrm{Ce}_{0.7} \mathrm{Zr}_{0.1} \mathrm{Y}_{0.2} \mathrm{O}_{3}-\delta$ ) were for the first time proposed and evaluated as anodes for $\mathrm{Ce}_{0.8} \mathrm{Sm}_{0.2} \mathrm{O}_{1.9}$ (SDC)-based SOFCs. Both $\mathrm{Ba}$ and $\mathrm{Sr}$ diffusion occurs at elevated temperatures during fabricating anode-supported half-cells; correspondingly, a thin electron-blocking interlayer is formed in situ at the anode/electrolyte interface. The presence of $\mathrm{Ba}$ ensures the formation of a $\mathrm{BaCeO}_{3}$-based electron-blocking layer, which has a very high ion transport number and completely eliminates the internal short circuit current across the SDC electrolyte. Sr incorporation can substantially promote the sintering activity of the anode and electrolyte and, hence, reduces the sintering temperature of the half-cells to $1150^{\circ} \mathrm{C}$. The electrochemical performance of the SDC-based cells varies significantly with the anode composition. Ni-Ba0.9 $\mathrm{Sr}_{0.1} \mathrm{Ce}_{0.7} \mathrm{Zr}_{0.1} \mathrm{Y}_{0.2} \mathrm{O}_{3}-\delta$ is demonstrated to be the optimal anode composition showing high open circuit voltages $\left(1.038 \mathrm{~V}\right.$ at $\left.650^{\circ} \mathrm{C}\right)$ and peak power densities $(677 \mathrm{~mW}$ $\mathrm{cm}^{-2}$ at $650^{\circ} \mathrm{C}$ ). These results present substantial progress in developing leakage current-free ceriabased SOFCs and also provide new insight into designing new cathode materials/structures for efficient ceria-based solid oxide electrolyzer cells.

Disciplines

Engineering | Physical Sciences and Mathematics

\section{Publication Details}

Gong, Z., Sun, W., Jin, Z., Miao, L. \& Liu, W. (2018). Barium- and Strontium-Containing Anode Materials toward Ceria-Based Solid Oxide Fuel Cells with High Open Circuit Voltages. ACS Applied Energy Materials, 1 (7), 3521-3528.
\end{abstract}




\title{
Barium- and Strontium-Containing Anode Materials toward Ceria-Based Solid Oxide Fuel Cells with High Open Circuit Voltages
}

\author{
Zheng Gonga ${ }^{\mathrm{a}}$, Wenping Sun ${ }^{\mathrm{b}, *}$, Zongzi Jin ${ }^{\mathrm{a}}$, Lina Miao ${ }^{\mathrm{a}}$, Wei Liu ${ }^{\mathrm{a}, \mathrm{c}, *}$ \\ ${ }^{a}$ CAS Key Laboratory of Materials for Energy Conversion \& Collaborative \\ Innovation Center of Suzhou Nano Science and Technology, University of Science \\ and Technology of China, Hefei 230026, PR China \\ ${ }^{b}$ Institute for Superconducting and Electronic Materials, Australian Institute of \\ Innovative Materials, University of Wollongong, Wollongong, NSW 2522, Australia \\ ${ }^{\mathrm{c}}$ Key Laboratory of Materials Physics, Institute of Solid State Physics, Chinese \\ Academy of Sciences, Hefei 230031, PR China
}

\footnotetext{
* Corresponding author.

E-mail address: wenping@uow.edu.au (W. Sun),wliu@ustc.edu.cn (W. Liu).
} 


\begin{abstract}
Developing ceria-based solid oxide fuel cells (SOFCs) with low cost, high power density and in particular high working efficiency is of great significance to practical applications. In this work, $\mathrm{Ba}$ and Sr-containing composites (Ni-Ba1-x $\left.\mathrm{Sr}_{\mathrm{x}} \mathrm{Ce}_{0.7} \mathrm{Zr}_{0.1} \mathrm{Y}_{0.2} \mathrm{O}_{3-\delta}\right)$ were for the first time proposed and evaluated as the anodes for $\mathrm{Ce}_{0.8} \mathrm{Sm}_{0.2} \mathrm{O}_{1.9}$ (SDC)-based SOFCs. Both $\mathrm{Ba}$ and $\mathrm{Sr}$ diffusion occurs at elevated temperatures during fabricating anode-supported half cells; correspondingly, a thin electron-blocking interlayer is formed in situ at the anode/electrolyte interface. The presence of $\mathrm{Ba}$ ensures the formation of $\mathrm{BaCeO}_{3}$-based electron-blocking layer, which has very high ion transport number and completely eliminate the internal short-circuit current across SDC electrolyte. Sr incorporation can substantially promote the sintering activity of the anode and electrolyte, and hence reduces the sintering temperature of the half cells to $1150{ }^{\circ} \mathrm{C}$. The electrochemical performance of the SDC-based cells varies significantly with the anode composition. $\mathrm{Ni}-\mathrm{Ba} 0.9 \mathrm{Sr}_{0.1} \mathrm{Ce}_{0.7} \mathrm{Zr}_{0.1} \mathrm{Y}_{0.2} \mathrm{O}_{3-\delta}$ is demonstrated to be the optimal anode composition showing high open circuit voltages $\left(1.038 \mathrm{~V}\right.$ at $\left.650{ }^{\circ} \mathrm{C}\right)$ and peak power densities $(677$ $\mathrm{mW} \mathrm{cm} \mathrm{cm}^{-2}$ at $650{ }^{\circ} \mathrm{C}$ ). These results present substantial progress in developing leakage current-free ceria-based SOFCs, and also provide new insight into designing new cathode materials/structures for efficient ceria-based solid oxide electrolyzer cells (SOECs).
\end{abstract}

Keywords:open circuit voltage, doped ceria, element diffusion, sintering, solid oxide fuel cells 


\section{Introduction}

As a promising alternative energy technology for next generation of power supply devices, solid oxide fuel cells (SOFC) have received significant research attention worldwide because of some appealing advantages, such as high energy efficiency, low pollutant emission and excellent fuel flexibility allowing the utilization of various kinds of hydrocarbon fuels ${ }^{1-3}$. However, high operating temperature usually causes severe performance degradation and requires long start-up time and expensive interconnectors/sealing materials, which is considered as a main obstacle that hinders SOFCs commercialization. Therefore, exploring SOFC operating at reduced temperatures and outputting high performance simultaneously is becoming very urgent. Employing highly conductive electrolyte materials plays a key role in lowering the operation temperature of $\mathrm{SOFCs}^{4}$. Among all types of well-established electrolyte materials, doped ceria (DCO) exhibits high ionic conductivity and remarkable chemical compatibility with electrode materials, and is considered to be one of the potential electrolyte materials for low-temperature SOFCs ${ }^{5}$. Regrettably, partial internal short-circuit behavior occurs when DCO electrolytes are exposed to fuel gas under operating conditions due to the $\mathrm{Ce}^{4+} / \mathrm{Ce}^{3+}$ redox reaction, which results in decreased open circuit voltages (OCVs) and hence low working efficiency ${ }^{6-7}$.

To suppress the electronic conduction across the DCO electrolyte, various approaches were proposed and investigated ${ }^{8-14}$. As a common strategy to protect DCO electrolyte from reduction, fabricating bi-layered electrolyte membranes have been suggested, including YSZ/SDC and BZCY/SDC, but the low oxygen ionic conductivity of YSZ and BZCY invalidate the merit of using DCO for developing low-temperature $\mathrm{SOFCs}^{9,}{ }^{14}$. In addition, for the case of YSZ/SDC, formation of $(\mathrm{Zr}, \mathrm{Ce}) \mathrm{O}_{2-\mathrm{x}}$ solid solution during sintering may further decrease the ionic conductivity of the electrolyte membrane and hence degrade the cell performance. In order to suppress DCO reduction and meanwhile maintain high electrolyte conductivity, Hibino et al. ${ }^{15-16}$ prepared a very thin $\mathrm{BaCe}_{1-\mathrm{x}} \mathrm{Sm}_{\mathrm{x}} \mathrm{O}_{3-\delta}$ layer on the SDC electrolyte surface via a solid-state reaction between $\mathrm{SDC}$ and $\mathrm{BaO}$ slurry. Following their work, Sun and Liu et al. ${ }^{10,} 12$ demonstrated that Ba-containing composites (doped 
$\mathrm{BaCeO}_{3}-\mathrm{Ni}$ ) can be directly employed as the anodes for DCO-based SOFC, and a thin $\mathrm{BaCeO}_{3}$-based electron-blocking layer is formed in situ during fabricating half cells. Besides, the thickness of the electron-blocking layer can be regulated by controlling the thickness of Ba-containing anode functional layer and/or the sintering temperature of half cells ${ }^{10,17}$.

In our previous work, we reported for the first time that $\mathrm{SrCeO}_{3}$-like electron-blocking layer is formed via $\mathrm{Sr}$ diffusion induced in-situ solid-state reaction at elevated temperatures by using $\mathrm{Ni}-\mathrm{SrCe}_{0.95} \mathrm{Yb}_{0.05} \mathrm{O}_{3-\delta}$ anode for SDC-based SOFCs ${ }^{18}$. Notably, the densification temperature of SDC electrolyte membrane is remarkably reduced compared with the cell with Ba-containing anode possibly because $\mathrm{Sr}$ is a good sintering aid for $\mathrm{SDC}^{19}$. However, there is still considerable leakage current for the cell with $\mathrm{SrCeO}_{3}$-based electron-blocking layer, which is due to the significant electronic conduction behavior of $\mathrm{SrCeO}_{3}$ under fuel cell conditions. Meanwhile, the delivered power performance is not competitive as compared with the cells with Ba-containing composite anode. Herein, $\mathrm{Ba}-$ and Sr-containing composites $\left(\mathrm{Ni}-\mathrm{Ba}_{1-\mathrm{x}} \mathrm{Sr}_{\mathrm{x}} \mathrm{Ce}_{0.7} \mathrm{Zr}_{0.1} \mathrm{Y}_{0.2} \mathrm{O}_{3-\delta}\right)$ were proposed as the anodes for SDC-based SOFCs in order to achieve low-temperature fabrication, high power performance and high open circuit voltages (high working efficiency). This concept takes advantages of both Ba and Sr diffusion strategy for DCO-based SOFC. Besides, Sr doping can also increase the chemical stability of doped $\mathrm{BaCeO}_{3}{ }^{20-21}$. In this case, Ba diffusion ensures the formation of $\mathrm{BaCeO}_{3}$-based electron-blocking layer with high ion transport number, while $\mathrm{Sr}$ diffusion helps to reduce the sintering temperature of the half cells. In addition, the dependence of electrochemical performance of the cells on the anode composition is investigated in detail, and an optimal anode composition is determined.

\section{Experimental}

\subsection{Sample preparation}

$\mathrm{NiO}-\mathrm{Ba}_{1-\mathrm{x}} \mathrm{Sr}_{\mathrm{x}} \mathrm{Ce}_{0.7} \mathrm{Zr}_{0.1} \mathrm{Y}_{0.2} \mathrm{O}_{3-\delta}(\mathrm{x}=0,0.1,0.2,0.3)$ composite powders with a weight ratio of 6:4 that are employed as the anodes for SDC-based SOFCs were all synthesized via a one-pot combustion process described in our previous work ${ }^{18}$. 
$\mathrm{Ni}\left(\mathrm{NO}_{3}\right)_{2} \cdot 6 \mathrm{H}_{2} \mathrm{O}, \mathrm{BaCO}_{3}, \mathrm{Sr}\left(\mathrm{NO}_{3}\right)_{2}, \mathrm{Ce}\left(\mathrm{NO}_{3}\right)_{3} \cdot 6 \mathrm{H}_{2} \mathrm{O}, \mathrm{Zr}\left(\mathrm{NO}_{3}\right)_{4} \cdot 5 \mathrm{H}_{2} \mathrm{O}$, and $\mathrm{Y}_{2} \mathrm{O}_{3}$ are the reagents for synthesizing the composite powders. After combustion, the as-prepared composite powders were calcined at $1000^{\circ} \mathrm{C}$ for $3 \mathrm{~h}$ in air.

Anode-supported half cells with NiO- $\mathrm{Ba}_{1-\mathrm{x}} \mathrm{Sr}_{\mathrm{x}} \mathrm{Ce}_{0.7} \mathrm{Zr}_{0.1} \mathrm{Y}_{0.2} \mathrm{O}_{3-\delta}$ anode supports and SDC electrolyte membranes were fabricated by a dry-pressing method. No pore-former was added into the composite anode. The diameter and the thickness of the green cells were about 15 and $1 \mathrm{~mm}$, respectively. Subsequently, the green half cells were sintered at 1250,1200 or $1150{ }^{\circ} \mathrm{C}$ for $5 \mathrm{~h}$ in air. Finally, a typical $\mathrm{Sm}_{0.5} \mathrm{Sr}_{0.5} \mathrm{CoO}_{3-\delta}-\mathrm{SDC}$ composite cathode slurry with a weight ratio of $6: 4$ used in our previous work was brush-painted on the SDC electrolyte surface of half cells, and then fired at $950{ }^{\circ} \mathrm{C}$ for $2 \mathrm{~h}$ to assemble a fuel cell with an active area of $0.195 \mathrm{~cm}^{2}$. $\mathrm{Ni}-\mathrm{Ba}_{1-\mathrm{x}} \mathrm{Sr}_{\mathrm{x}} \mathrm{Ce}_{0.7} \mathrm{Zr}_{0.1} \mathrm{Y}_{0.2} \mathrm{O}_{3-\delta}$ anodes will be obtained after NiO-Ba1-x $\mathrm{Sr}_{\mathrm{x}} \mathrm{Ce}_{0.7} \mathrm{Zr}_{0.1} \mathrm{Y}_{0.2}$ $\mathrm{O}_{3-\delta}$ anode supports are reduced by the fuel gas during cell testing.

In order to illustrate the different diffusion phenomena of $\mathrm{Sr}$ and $\mathrm{Ba}$ from anode to electrolyte during fuel cell sintering and clarify the reason for the reduced sintering temperature of SDC when Sr-containing anode was used for SDC-based SOFC, $\mathrm{BaCO}_{3}$ and $\mathrm{SrCO}_{3}$ suspensions were drop-coated on the SDC pellets pre-sintered at $800{ }^{\circ} \mathrm{C}$ for $3 \mathrm{~h}$, and then annealed at $1300{ }^{\circ} \mathrm{C}$ for $5 \mathrm{~h}$. Ba and $\mathrm{Sr}$ diffusion from $\mathrm{BaCO}_{3}$ and $\mathrm{SrCO}_{3}$ occur during high-temperature sintering, which is similar to the situation of Ba- or Sr-containing anode supported SDC-based fuel cells, respectively. The schematic diagram for this experiment is shown in Figure S1 (Supporting Information). After annealing, the SDC pellets were collected for further characterization. To investigate the phase composition and the chemical states of the elements in the electron-blocking layer, SDC powders were placed between two green $\mathrm{Ba}_{1-\mathrm{x}} \mathrm{Sr}_{\mathrm{x}} \mathrm{Ce} 0.7 \mathrm{Zr}_{0.1} \mathrm{Y}_{0.2} \mathrm{O}_{3-\delta}(0.1 \leq \mathrm{x} \leq 0.3)$ pellets and then annealed at $1300{ }^{\circ} \mathrm{C}$ for $10 \mathrm{~h}$ to simulate the sintering process of $\mathrm{NiO}-\mathrm{Ba}_{1-\mathrm{x}} \mathrm{Sr}_{\mathrm{x}} \mathrm{Ce}_{0.7} \mathrm{Zr}_{0.1} \mathrm{Y}_{0.2} \mathrm{O}_{3-\delta} / \mathrm{SDC}$ half cells, as described elsewhere ${ }^{18,22}$.

2.2. Electrochemistry testing and other characterizations

The single cell was attached to a home-made cell testing equipment by using Ag paste for sealing. After drying at $80{ }^{\circ} \mathrm{C}$ for $6 \mathrm{~h}$, the single cell was tested from 650 to 
$500{ }^{\circ} \mathrm{C}$ at $50{ }^{\circ} \mathrm{C}$ intervals with $\sim 3 \% \mathrm{H}_{2} \mathrm{O}$ humidified hydrogen $\left(40 \mathrm{ml} \mathrm{min}^{-1}\right)$ as the fuel and the static air as the oxidant. The current-voltage curves of the cells were measured by using a DC electronic load (ITECH Electronics model IT8511). The OCVs of the fuel cells were obtained from both a DC Electronic Load and EIS measured under open circuit condition. The crystal structures of $\mathrm{NiO}-\mathrm{Ba}_{1-\mathrm{x}} \mathrm{Sr}_{\mathrm{x}} \mathrm{Ce}_{0.7} \mathrm{Zr}_{0.1} \mathrm{Y}_{0.2} \mathrm{O}_{3-\delta}$ composite powders were characterized by an X-ray diffractometer (Rigaku TTR-III) with $\mathrm{Cu} \mathrm{Ka}$ radiation. The microstructures and elemental distribution of the tested single cells and treated SDC pellets were investigated by a scanning electron microscope (SEM, JEOL JSM-6700F) equipped with an energy-dispersive X-ray spectroscopy system (EDS). The sintering shrinkage behaviors of $\mathrm{NiO}-\mathrm{Ba}_{1-\mathrm{x}} \mathrm{Sr}_{\mathrm{x}} \mathrm{Ce}_{0.7} \mathrm{Zr}_{0.1} \mathrm{Y}_{0.2} \mathrm{O}_{3-\delta}$ composite anode materials were examined using dilatometer measurement (Netzsch DIL 402E). The specimens were fabricated by die-pressing with dimensions of $30 \mathrm{~mm} \times 4 \mathrm{~mm} \times 2 \mathrm{~mm}$. X-ray photon spectroscopy (XPS, Thermo ESCALAB 250) and inVia Raman Microscope (Renishaw) with $532 \mathrm{~nm}$ incident laser excitation were used to investigate the phase composition and the chemical states of the elements of the nominal SDC powders calcined between two $\mathrm{Ba}_{1-\mathrm{x}} \mathrm{Sr}_{\mathrm{x}} \mathrm{Ce}_{0.7} \mathrm{Zr}_{0.1} \mathrm{Y}_{0.2} \mathrm{O}_{3-\delta}$ pellets.

\section{Results and discussion}

The XRD patterns of $\mathrm{NiO}-\mathrm{Ba}_{1-\mathrm{x}} \mathrm{Sr}_{\mathrm{x}} \mathrm{Ce}_{0.7} \mathrm{Zr}_{0.1} \mathrm{Y}_{0.2} \mathrm{O}_{3-\delta} \quad(0 \leq \mathrm{x} \leq 0.3)$ composites calcined at $1000{ }^{\circ} \mathrm{C}$ for $3 \mathrm{~h}$ are shown in Figure 1. The indexing of the XRD patterns clearly reveals all the samples present well crystallized perovskite $\left(\mathrm{Ba}_{1-\mathrm{x}} \mathrm{Sr}_{\mathrm{x}} \mathrm{Ce}_{0.7} \mathrm{Zr}_{0.1} \mathrm{Y}_{0.2} \mathrm{O}_{3-\delta}\right)$ and cubic $(\mathrm{NiO})$ phase structures and no impurity diffraction peaks are detected over the range of $\operatorname{Sr}$ doping content $(0 \leq x \leq 0.3)$. Shown in Figure 2 are SEM images of the surface and cross-sectional morphology of the SDC electrolyte membranes in the NiO-Ba1-x $\mathrm{Sr}_{\mathrm{x}} \mathrm{Ce}_{0.7} \mathrm{Zr}_{0.1} \mathrm{Y}_{0.2} \mathrm{O}_{3-\delta} / \mathrm{SDC}(0.1 \leq \mathrm{x} \leq 0.3)$ half cells sintered at $1150{ }^{\circ} \mathrm{C}$ for $5 \mathrm{~h}$. One can see that the sintering ability of the SDC electrolyte membrane is closely associated with the NiO-Ba $a_{1-x} \operatorname{Sr}_{x} C e_{0.7} \mathrm{Zr}_{0.1} \mathrm{Y}_{0.2} \mathrm{O}_{3-\delta}$ anode, and both the electrolyte density and grain size increase significantly with increasing Sr content in the anode. The SDC electrolyte membrane is fully dense for the cell with $\mathrm{Ba}_{0.7} \mathrm{Sr}_{0.3} \mathrm{Ce}_{0.7} \mathrm{Zr}_{0.1} \mathrm{Y}_{0.2} \mathrm{O}_{3-\delta}$ anode support, which also exhibits the largest 
grain size. The results suggest that the densification temperature of the SDC electrolyte membrane can be well controlled by tuning $\mathrm{Sr}$ doping in the $\mathrm{NiO}-\mathrm{Ba}_{1-\mathrm{x}} \mathrm{Sr}_{\mathrm{x}} \mathrm{Ce}_{0.7} \mathrm{Zr}_{0.1} \mathrm{Y}_{0.2} \mathrm{O}_{3-\delta}$ anode support. It should be noted that the densification temperature of the anode-supported SDC electrolyte membrane is decreased by nearly $200{ }^{\circ} \mathrm{C}$ without using additional sintering aids as compared with those SDC-based cells with traditional $\mathrm{NiO}-\mathrm{SDC}$ or $\mathrm{NiO}-\mathrm{BZCY}$ anode supports ${ }^{10,23}$.

The substantially decreased densification temperature might be ascribed to the improved sintering activity of anode and/or electrolyte. Basically, the shrinkage of anode support during sintering is one key driving force for the densification of the electrolyte membrane ${ }^{24}$. To verify the formulated interpretation for the reduced sintering temperature of SDC electrolyte, the sintering shrinkage behaviors of $\mathrm{NiO}-\mathrm{Ba}_{1-\mathrm{x}} \mathrm{Sr}_{\mathrm{x}} \mathrm{Ce}_{0.7} \mathrm{Zr}_{0.1} \mathrm{Y}_{0.2} \mathrm{O}_{3-\delta}(0 \leq \mathrm{x} \leq 0.3)$ specimens were measured and shown in Figure 3. One can see that, when the temperature is increased to $1200{ }^{\circ} \mathrm{C}$, the shrinkage of NiO-Ba0.9 $\mathrm{Sr}_{0.1} \mathrm{Ce}_{0.7} \mathrm{Zr}_{0.1} \mathrm{Y}_{0.2} \mathrm{O}_{3-\delta} \quad(\mathrm{NiO}-\mathrm{BSZCY} 91)$ and $\mathrm{NiO}-\mathrm{Ba} 0.8 \mathrm{Sr}_{0.2} \mathrm{Ce}_{0.7} \mathrm{Zr}_{0.1} \mathrm{Y}_{0.2} \mathrm{O}_{3-\delta} \quad(\mathrm{NiO}-\mathrm{BSZCY} 82) \quad$ reaches $12.5 \%$ and $15.5 \%$, respectively, and the corresponding value for $\mathrm{NiO}-\mathrm{BaCe}_{0.7} \mathrm{Zr}_{0.1} \mathrm{Y}_{0.2} \mathrm{O}_{3-\delta}(\mathrm{NiO}-\mathrm{BZCY})$ specimen is only $6.8 \%$, indicating that $\mathrm{Sr}$ doping greatly promotes the sintering activity of the anode support. Similar sintering shrinkage behavior is also observed in $\mathrm{NiO}-\mathrm{Ba}_{1-\mathrm{x}} \mathrm{Sr}_{\mathrm{x}} \mathrm{Ce}_{0.7} \mathrm{Zr}_{0.1} \mathrm{Y}_{0.2} \mathrm{O}_{3-\delta} / \mathrm{SDC}$ half cells sintered at $1200{ }^{\circ} \mathrm{C}$ for $5 \mathrm{~h}$, as shown in Figure S2(Supporting Information), further confirming the positive role that Sr plays in anode sintering. It has to be mentioned that, NiO-BSZCY73 shows similar shrinkage percentage to NiO-BSZCY82 at $1200{ }^{\circ} \mathrm{C}$, but the electrolyte membrane of the cell with NiO-BSZCY73 anode support exhibits higher density and larger grain size (Figure 3). Therefore, it can be speculated that the improved sintering activity of the electrolyte might be another possible reason for the reduced sintering temperature of the cells with Sr-containing anode, which is in great part due to $\mathrm{Sr}$ diffusion from anode to SDC electrolyte.

In order to gain more insights into understanding the effect of $\mathrm{Sr}$ diffusion on the densification of SDC and the different sintering promotion behavior of $\mathrm{Ba}$ and $\mathrm{Sr}, 150$ $\mu \mathrm{L} \mathrm{BaCO}_{3}$ and $\mathrm{SrCO}_{3}$ suspension was coated on the pre-sintered SDC pellets, 
respectively, and then samples were sintered at $1300{ }^{\circ} \mathrm{C}$ for $5 \mathrm{~h}$ to simulate the sintering process of SDC-based SOFCs with Ba- or Sr-containing anode supports, as schematically illustrated in Figure S1. Sr and $\mathrm{Ba}$ from the coated $\mathrm{BaCO}_{3}$ and $\mathrm{SrCO}_{3}$ films will diffuse into SDC pellets and react with SDC accordingly during the sintering process. Shown in Figure 4 are the SEM-EDS analysis in line-scan mode and element mapping results of the sintered SDC pellets. It can be clear seen that both $\mathrm{Ba}$ and $\mathrm{Sr}$ elements diffuse into the SDC pellets, but show substantially different diffusion kinetics. The diffusion distance of $\mathrm{Sr}$ (greater than $220 \mu \mathrm{m}$ ) is nearly double that of $\mathrm{Ba}(120 \mu \mathrm{m})$. The faster diffusion kinetics of $\mathrm{Sr}$ can be ascribed to the smaller ionic radius of $\mathrm{Sr}$ than that of $\mathrm{Ba}^{25}$. It is worth noting that both $\mathrm{Sr}$ and $\mathrm{Ba}$ diffusion into the SDC pellets can promote the sintering activity, and Ba even appears to be more effective (Figure S3 Supporting Information). Given Sr diffuses much faster than $\mathrm{Ba}$, more $\mathrm{Sr}$ would be incorporated into SDC electrolyte membrane during cell sintering, and consequently the SDC membrane would get densified more easily. Therefore, it can be concluded that $\mathrm{Sr}$ diffusion should also play a critical role in reducing the sintering temperature of the cells with Sr-containing anode supports.

The electrochemical performance of the cells with different $\mathrm{NiO}-\mathrm{Ba}_{1-\mathrm{x}} \mathrm{Sr}_{\mathrm{x}} \mathrm{Ce} 0.7 \mathrm{Zr}_{0.1} \mathrm{Y}_{0.2} \mathrm{O}_{3-\delta}(0 \leq \mathrm{x} \leq 0.3)$ anode supports were evaluated with humidified hydrogen $\left(\sim 3 \% \mathrm{H}_{2} \mathrm{O}\right)$ as the fuel and static air as the oxidant. The temperature dependence of the OCVs of the cells with different anodes sintered at 1200 or $1150{ }^{\circ} \mathrm{C}$ are shown in Figure 5. For the cells sintered at $1150{ }^{\circ} \mathrm{C}$, the $\mathrm{OCV}$ increase significantly with increasing $\mathrm{Sr}$ content in the anode, which is in good agreement with the density of the sintered SDC electrolyte membrane as shown in

Figure 2. Although the OCVs of the cells with NiO-BSZCY91 and NiO-BSZCY82 anode supports are higher than the typical DCO-based cells, the OCVs are still obviously lower than the theoretical values, which can be ascribed to the ununiformity of these electron-blocking layers and the porosity of the electrolyte membranes (Figure 2). In contrast, the OCVs of the cell with NiO-BSZCY73 anode support sintered at $1150{ }^{\circ} \mathrm{C}$ achieve as high as $1.043,1.056,1.072$, and $1.082 \mathrm{~V}$ at 650,600 , 550 , and $500{ }^{\circ} \mathrm{C}$, respectively, which is very close to the theoretical OCV values. The 
elimination of the internal short-circuit current should be attributed to the formation of the electron-blocking layer together with the dense electrolyte membrane of the cell with NiO-BSZCY73 anode support. As can be seen from Figure 5, the internal short-circuit behavior is effectively suppressed for the cells with NiO-BSZCY91, NiO-BSZCY82 and NiO-BSZCY73 as anodes with further increasing sintering temperature to $1200{ }^{\circ} \mathrm{C}$, correspondingly OCVs are $1.038,1.065$ and $1.057 \mathrm{~V}$ at $650{ }^{\circ} \mathrm{C}$, respectively, while the cell with NiO-BZCY anode sintered at $1200{ }^{\circ} \mathrm{C}$ still exhibits inferior OCVs, which is caused mainly by the porous SDC electrolyte membrane (Figure S4 Supporting Information) due to the poor sintering ability of NiO-BZCY and no Sr elements diffusion promoting the sintering of SDC electrolyte. The results demonstrate that, as compared with the previously reported cell with $\mathrm{NiO}-\mathrm{SrCeO}_{3}$ anode support ${ }^{18}$, the incorporation of $\mathrm{Ba}$ can substantially improve the electron-blocking capability of the in-situ formed interlayer. Meanwhile, $\mathrm{Sr}$ is critically important to get fully dense SDC electrolyte membranes at reduced temperatures.

The formation of the electron-blocking interlayer was investigated by SEM-EDS analysis and element mapping. As expected, a Ba- and Sr-containing electron-blocking layer, around $2 \mu \mathrm{m}$ in thickness, can be observed at the anode/SDC electrolyte interface as shown in Figure S5 (Supporting Information), which is similar to the previous reports with $\mathrm{NiO}-\mathrm{BaCeO}_{3}$ or $\mathrm{NiO}-\mathrm{BaZrO} 3$ anode supports ${ }^{10,12,22}$. To further investigate the phase composition and the chemical states of the elements in the electron-blocking interlayer, SDC powders were placed between two green $\mathrm{Ba}_{1-\mathrm{x}} \mathrm{Sr}_{\mathrm{x}} \mathrm{Ce} 0.7 \mathrm{Zr}_{0.1} \mathrm{Y}_{0.2} \mathrm{O}_{3-\delta}$ pellets and then annealed at $1300{ }^{\circ} \mathrm{C}$ for $10 \mathrm{~h}$ to simulate the diffusion behaviors of $\mathrm{Ba}$ and $\mathrm{Sr}$ during sintering $\mathrm{NiO}-\mathrm{Ba}_{1-\mathrm{x}} \mathrm{Sr}_{\mathrm{x}} \mathrm{Ce}_{0.7} \mathrm{Zr}_{0.1} \mathrm{Y}_{0.2} \mathrm{O}_{3-\delta} / \mathrm{SDC}$ half cells. Ba and $\mathrm{Sr}$ will diffuse and then react with SDC powders at elevated temperatures. The collected SDC powders named SDC-BS91, SDC-BS82, and SDC-BS73 for $\mathrm{x}=0.1, \mathrm{x}=0.2$, and $\mathrm{x}=0.3$, respectively, were then characterized by Raman spectroscopy and X-ray photoelectron spectra (XPS). The Raman spectra of the annealed SDC powders in comparison with as-prepared $\mathrm{BaCe}_{0.8} \mathrm{Sm}_{0.2} \mathrm{O}_{3-\delta}$, $\mathrm{SrCe}_{0.95} \mathrm{Sm}_{0.05} \mathrm{O}_{3-\delta}$ and $\mathrm{SDC}$ powders are shown in Figure 6a. The most intense 
characteristic peaks of $\mathrm{BaCe}_{0.8} \mathrm{Sm}_{0.2} \mathrm{O}_{3-\delta}$ and $\mathrm{SrCe}_{0.95} \mathrm{Sm}_{0.05} \mathrm{O}_{3-\delta}$ locate at around 348 and $343 \mathrm{~cm}^{-1}$, respectively ${ }^{18,22,26}$, and these peaks can be assigned to Ce-O stretching vibration of the $\mathrm{CeO}_{6}$ octahedra ${ }^{18,22,26}$. As can be seen, the characteristic peak appears for all the annealed SDC samples, suggesting the formation of the $(\mathrm{Ba}, \mathrm{Sr}) \mathrm{CeO}_{3}$-like phase $^{18,22}$. Notably, the characteristic peak tends to shift negatively with increasing $\mathrm{Sr}$ doping in $\mathrm{Ba}_{1-\mathrm{x}} \mathrm{Sr}_{\mathrm{x}} \mathrm{Ce}_{0.7} \mathrm{Zr}_{0.1} \mathrm{Y}_{0.2} \mathrm{O}_{3-\delta}$, indicating that the $(\mathrm{Ba}, \mathrm{Sr}) \mathrm{CeO}_{3}$-like phase contains more Sr. Figure $6 \mathbf{b}$ shows the full survey XPS spectra of SDC-BS91 powders. Peaks corresponding to oxygen $(\mathrm{O} 1 \mathrm{~s}$ at $\sim 530 \mathrm{eV})$, cerium $(\mathrm{Ce} 3 \mathrm{~d}$ at $\sim 882$ $\mathrm{eV})$, strontium $(\mathrm{Sr} 3 \mathrm{~d}$ at $\sim 134 \mathrm{eV}$ ) and barium (Ba 3d at $780 \mathrm{eV})$ can be clearly detected. The Sr 3d spectra for SDC-BS91, SDC-BS82, and SDC-BS73 powders can be fitted with three peaks, as shown in Figure 6c. The peaks with binding energies of $\sim 132.9$ and $\sim 134.8 \mathrm{eV}$ are attributed to $\mathrm{Sr}^{2+}$ in the perovskite oxide ${ }^{25,27}$, which is consistent with the result of BSZCY91, and this is also good evidence to support the formation of $(\mathrm{Ba}, \mathrm{Sr}) \mathrm{CeO}_{3}$-like phase. The peak with a binding energy of $\sim 130.2 \mathrm{eV}$ likely corresponds to $\mathrm{SrO}_{1-\mathrm{x}}$ species deposited on the surface of the annealed SDC powders ${ }^{27-29}$. In addition to be involved in the chemical reaction with SDC, the residual strontium oxide would also act as an effect sintering aid for the SDC electrolyte membrane as discussed previously ${ }^{19}$. High-resolution O 1s spectra of SDC, SDC-BS91, and BSZCY91 can be fitted with four peaks (Figure 6d). The peaks centered at $\sim 528.7, \sim 530.3, \sim 531.2$ and $\sim 532.3 \mathrm{eV}$ are attributed to the lattice oxygen species $\mathrm{O}^{2-}$, reactive oxygen species, chemisorbed $\mathrm{H}_{2} \mathrm{O}$ or $\mathrm{CO}_{3}{ }^{2-}$, and $-\mathrm{OH}^{-}$or $\mathrm{O}^{2}$, respectively ${ }^{30-32}$. Compared to SDC, SDC-BS91 shows a significantly enhanced peak corresponding to chemisorbed $\mathrm{H}_{2} \mathrm{O}$ or $\mathrm{CO}_{3}{ }^{2-}$, which is similar to that of BSZCY91. Basically, $\mathrm{BaCeO}_{3}$-based proton conductors are easily to adsorb moisture and $\mathrm{CO}_{2}{ }^{13}$, ${ }^{25,33}$, and hence the $\mathrm{O} 1 \mathrm{~s}$ spectra further indicate the presence of $(\mathrm{Ba}, \mathrm{Sr}) \mathrm{CeO}_{3}$-like phase.

Figure 7 shows the SEM images of the cross-sectional morphologies of the tested single cells with different anodes sintered at $1200{ }^{\circ} \mathrm{C}$ for $5 \mathrm{~h}$. One can see that the tested anode-supported fuel cells have almost identically thick cathode $(\sim 12 \mu \mathrm{m})$ and electrolyte $(\sim 15 \mu \mathrm{m})$. The thickness of anode substrate is about $1 \mathrm{~mm}$, and all the 
electrolyte membranes are fully dense except for the cell with the NiO-BZCY anode support. Besides, all the electrolyte membranes are closely bonded with the electrodes, suggesting good compatibility of the electrolyte and electrodes. The I-V and I-P curves of the single cells with different anodes at $650{ }^{\circ} \mathrm{C}$ are shown in Figure 8a. In addition to the densification temperature of SDC electrolyte membrane, the power density of the cells also shows high dependence on the anode composition. At $650{ }^{\circ} \mathrm{C}$, the maximum power densities (MPD) are 677, 562, 464, and $275 \mathrm{mWcm}^{-2}$ for the cells with Ni-BSZCY91, Ni-BSZCY82, Ni-BSZCY73 and Ni-BZCY anodes, respectively. The cell with Ni-BSZCY91 anode outputs the highest peak power density, which is obviously greater than that of the cell with NiO-BZCY anode sintered at the same temperature. Although the power performance decreases with increasing the Sr-doping content, the MPD are still higher than that of the cell with NiO-BZCY anode. Considering the relatively low sintering temperature (low fabrication cost) and high OCVs (high working efficiency), the new SDC-based cell has great potential for practical application. According to the above results, Ni-BSZCY91 composite is demonstrated to be the optimal composition as anode for SDC-based SOFCs towards high power density, high OCVs and low densification temperature. Figure $\mathbf{8 b}$ shows the electrochemical performance of the cell with NiO-BSZCY91 anode at low operating temperatures. Besides, the cell also shows a good stability. As shown in Figure 9, no obvious performance degradation can be observed during the period of testing.

To further figure out the power performance dependence on the anode composition of the fuel cells, electrochemical impedance spectra (EIS) were measured under open circuit conditions at $650{ }^{\circ} \mathrm{C}$ and are shown in Figure 10. One can see that both ohmic resistance $\left(R_{0}\right)$ and polarization resistance $\left(R_{p}\right)$ increase with increasing $\mathrm{Sr}$ content from 0.1 to 0.3 . The $\mathrm{R}_{\mathrm{o}}$ values are determined to be $0.223,0.244$, and $0.291 \Omega$ $\mathrm{cm}^{2}$ and $\mathrm{R}_{\mathrm{p}}$ values are $0.516,0.627$, and $0.658 \Omega \mathrm{cm}^{2}$ at $650{ }^{\circ} \mathrm{C}$ for the cells with Ni-BSZCY91, Ni-BSZCY82, and Ni-BSZCY73 anodes, respectively. It was reported that the ionic conductivity of $\mathrm{Ba}_{1-\mathrm{x}} \mathrm{Sr}_{\mathrm{x}} \mathrm{Ce}_{0.6} \mathrm{Zr}_{0.2} \mathrm{Y}_{0.2} \mathrm{O}_{3-\delta}$ decreases with increasing $\mathrm{Sr}$ doping content ${ }^{21}$. Therefore, the increased $R_{p}$ should be ascribed to the decreased 
ionic conductivity of $\mathrm{Ba}_{1-\mathrm{x}} \mathrm{Sr}_{\mathrm{x}} \mathrm{Ce}_{0.7} \mathrm{Zr}_{0.1} \mathrm{Y}_{0.2} \mathrm{O}_{3-\delta}$ in the anodes, which basically hinders ion transport and eventually decrease electrode reaction kinetics. XPS results (Figure S6 Supporting Information) show that Sr can easily diffuse into the SDC electrolyte and the amount of $\mathrm{Sr}$ diffusion is proportional to $\mathrm{Sr}$ content in the anode. Given all the fuel cells were fabricated and tested under same conditions, the increased $R_{0}$ should be due to the decreased ionic conductivity of the electrolyte because the ionic conductivity of the electrolyte is affected by the diffused $\mathrm{Sr}$ elements ${ }^{19}$ and ionic resistance of the electrolyte dominate the $\mathrm{R}_{\mathrm{o}}$ of the cell, suggesting $\mathrm{Sr}$ diffusion into the SDC electrolyte is detrimental to the electrolyte conductivity. The high Ro value of the cell with Ni-BZCY anode can be ascribed to the lower density of the SDC electrolyte membrane.

\section{Conclusions}

Ba- and Sr-containing composites were successfully demonstrated as potential anodes for SDC-based SOFCs to achieve low-temperature fabrication, high efficiency and power performance. Ba diffusion improved the electron-blocking capability of the in-situ formed anode/electrolyte interlayer while $\mathrm{Sr}$ diffusion reduced the sintering temperature of the SDC-based half cells. It turns out that $\mathrm{Ni}-\mathrm{Ba} 0.9 \mathrm{Sr}_{0.1} \mathrm{Ce}_{0.7} \mathrm{Zr}_{0.1} \mathrm{Y}_{0.2} \mathrm{O}_{3-\delta}$ is the optimal anode composition, and the internal short circuit was effectively eliminated by an in-situ formed Ba- and Sr-containing thin electron-blocking layer at the temperature as low as $1200{ }^{\circ} \mathrm{C}$, which was composed of $\mathrm{SDC}$ and $(\mathrm{Ba}, \mathrm{Sr}) \mathrm{CeO}_{3}$-like phase. As a result, the OCV of the fuel cell achieved $1.038 \mathrm{~V}$ at $650{ }^{\circ} \mathrm{C}$ with a peak power density of $677 \mathrm{~mW} \mathrm{~cm}$. The excellent electrochemical performance suggests that the Ba- and Sr-containing composites are promising electrodes for DCO-based SOFCs and SOECs with high working efficiency.

\section{ASSOCIATED CONTENT}

\section{Supporting Information}

Schematic diagram of the procedure for preparing $\mathrm{Ba} / \mathrm{Sr}$ containing $\mathrm{SDC}$ and additional experimental results of linear shrinkage of half cells, SEM images, 
SEM-EDS and XPS analysis available.

\section{AUTHOR INFORMATION}

\section{Corresponding Authors}

*wenping@uow.edu.au (W. Sun)

*wliu@ustc.edu.cn (W. Liu)

\section{Acknowledgments}

This work was supported by the National Natural Science Foundation of China (Grant Nos: 21676261, U1632131 and 51502004). W. Sun acknowledges financial support from the Australian Research Council (ARC) DECRA Grant (DE160100596).

\section{References}

1. Shao, Z. P.; Haile, S. M., A High-Performance Cathode for the Next Generation of Solid-Oxide Fuel Cells. Nature 2004, 431, 170-173.

2. Joh, D. W.; Park, J. H.; Kim, D.; Wachsman, E. D.; Lee, K. T., Functionally Graded Bismuth Oxide/Zirconia Bilayer Electrolytes for High-Performance Intermediate-Temperature Solid Oxide Fuel Cells (IT-SOFCs). ACS Appl. Mater. Interfaces 2017, 9, 8443-8449.

3. Zhang, Y.; Yang, G.; Chen, G.; Ran, R.; Zhou, W.; Shao, Z., Evaluation of the $\mathrm{CO}_{2}$ Poisoning Effect on a Highly Active Cathode $\mathrm{SrSc}_{0.175} \mathrm{Nb}_{0.025} \mathrm{Co}_{0.8} \mathrm{O}_{3-\delta}$ in the Oxygen Reduction Reaction. ACS Appl. Mater. Interfaces 2016, 8, 3003-11.

4. Malavasi, L.; Fisher, C. A.; Islam, M. S., Oxide-ion and proton conducting electrolyte materials for clean energy applications: structural and mechanistic features. Chem. Soc. Rev. 2010, 39, 4370-4387.

5. Lee, J. G.; Park, J. H.; Shul, Y. G., Tailoring gadolinium-doped ceria-based solid oxide fuel cells to achieve $2 \mathrm{~W} \mathrm{~cm}^{-2}$ at $550{ }^{\circ} \mathrm{C}$. Nat. Commun. 2014, 5, 1-10.

6. Zhang, Y.; Knibbe, R.; Sunarso, J.; Zhong, Y.; Zhou, W.; Shao, Z.; Zhu, Z., Recent Progress on Advanced Materials for Solid-Oxide Fuel Cells Operating Below 
$500{ }^{\circ} \mathrm{C}$. Adv. Mater. 2017, 29, 1700132-1700164.

7. Chen, Y.; Zhang, Y.; Baker, J.; Majumdar, P.; Yang, Z.; Han, M.; Chen, F., Hierarchically oriented macroporous anode-supported solid oxide fuel cell with thin ceria electrolyte film. ACS Appl. Mater. Interfaces 2014, 6, 5130-5136.

8. Zhang, X.; Robertson, M.; Decès-Petit, C.; Xie, Y. S.; Hui, R.; Qu, W.; Kesler, O.; Maric, R.; Ghosh, D., Solid Oxide Fuel Cells with Bi-Layered Electrolyte Structure. J. Power Sources 2008, 175, 800-805.

9. Sun, W. P.; Shi, Z.; Wang, Z. T.; Liu, W., Bilayered $\mathrm{BaZr}_{0.1} \mathrm{Ce}_{0.7} \mathrm{Y}_{0.2} \mathrm{O}_{3-\delta} /$ $\mathrm{Ce}_{0.8} \mathrm{Sm}_{0.2} \mathrm{O}_{2-\delta}$ Electrolyte Membranes for Solid Oxide Fuel Cells with High Open Circuit Voltages. J. Membrane Sci. 2014, 476, 394-398.

10. Sun, W. P.; Liu, W., A Novel Ceria-Based Solid Oxide Fuel Cell Free from Internal Short Circuit. J. Power Sources 2012,217, 114-119.

11. Wachsman, E. D.; Lee, K. T., Lowering the Temperature of Solid Oxide Fuel Cells. Science 2011, 334 , 935-939.

12. Liu, M. F.; Ding, D.; Bai, Y. H.; He, T.; Liu, M. L., An Efficient SOFC Based on Samaria-Doped Ceria (SDC) Electrolyte. J .Electrochem. Soc. 2012, 159, B661-B665. 13. Sun, W.; Jiang, Y.; Wang, Y.; Fang, S.; Zhu, Z.; Liu, W., A Novel Electronic Current-Blocked Stable Mixed Ionic onductor for Solid Oxide Fuel Cells. J. Power Sources 2011, 196, 62-68.

14. Qian, J.; Tao, Z.; Xiao, J.; Jiang, G.; Liu, W., Performance Improvement of Ceria-Based Solid Oxide Fuel Cells with Yttria-Stabilized Zirconia as an Electronic Blocking Layer by Pulsed Laser Deposition. Int. J. Hydrogen Energ. 2013, 38, 2407-2412.

15. Hirabayashi, D.; Tomita, A.; Hibino, T.; Nagao, M.; Sano, M., Design of a Reduction-Resistant $\mathrm{Ce}_{0.8} \mathrm{Sm}_{0.2} \mathrm{O}_{1.9}$ Electrolyte through Growth of a Thin $\mathrm{BaCe}_{1-\mathrm{x}} \mathrm{Sm}_{\mathrm{x}} \mathrm{O}_{3-\delta}$ Layer over Electrolyte Surface. Electrochem. Solid-State Lett. 2004, 7, A318-A320.

16. Hirabayashi, D.; Tomita, A.; Teranishi, S.; Hibino, T.; Sano, M., Improvement of a Reduction-Resistant $\mathrm{Ce}_{0.8} \mathrm{Sm}_{0.2} \mathrm{O}_{1.9}$ Electrolyte by Optimizing a Thin $\mathrm{BaCe}_{1-\mathrm{x}} \mathrm{Sm}_{\mathrm{x}} \mathrm{O}_{3-\delta}$ Layer for Intermediate-Temperature SOFCs. Solid State Ionics 2005, 176, 881-887. 
17. Gong, Z.; Sun, W. P.; Shan, D.; Wu, Y. S.; Liu, W., Tuning the Thickness of Ba-Containing "Functional" Layer toward High-Performance Ceria-Based Solid Oxide Fuel Cells. ACS Appl. Mater. Interfaces 2016, 8, 10835-10840.

18. Gong, Z.; Sun, W.; Cao, J.; Wu, Y.; Miao, L.; Liu, W., A New in situ Strategy to Eliminate Partial Internal Short Circuit in $\mathrm{Ce}_{0.8} \mathrm{Sm}_{0.2} \mathrm{O}_{1.9}$-Based Solid Oxide Fuel Cells. J. Mater. Chem. A 2017, 5, 12873-12878.

19. Zheng, Y.; He, S.; Ge, L.; Zhou, M.; Chen, H.; Guo, L., Effect of Sr on Sm-doped Ceria Electrolyte. Int. J. Hydrogen Energ.2011, 36, 5128-5135.

20. Kannan, R.; Singh, K.; Gill, S.; Furstenhaupt, T.; Thangadurai, V., Chemically Stable Proton Conducting Doped $\mathrm{BaCeO}_{3-\delta}$ no more Fear to SOFC Wastes. Sci. Rep. 2013, 3, 2138-2142.

21. Lee, K. R.; Tseng, C. J.; Chang, J. K.; Hung, I. M.; Lin, J. C.; Lee, S. W., Strontium Doping Effect on Phase Homogeneity and Conductivity of $\mathrm{Ba}_{1-\mathrm{x}} \mathrm{Sr}_{\mathrm{x}} \mathrm{Ce}_{0.6} \mathrm{Zr}_{0.2} \mathrm{Y}_{0.2} \mathrm{O}_{3-\delta}$ Proton-Conducting Oxides. Int. J. Hydrogen Energ. 2013, 38, 11097-11103.

22. Sun, W. P.; Shi, Z.; Qian, J.; Wang, Z. T.; Liu, W., In-situ Formed $\mathrm{Ce}_{0.8} \mathrm{Sm}_{0.2} \mathrm{O}_{2-\delta} @ \mathrm{Ba}(\mathrm{Ce}, \mathrm{Zr})_{1-\mathrm{x}}(\mathrm{Sm}, \quad \mathrm{Y})_{\mathrm{x}} \mathrm{O}_{3-\delta} \mathrm{Core} /$ Shell Electron-Blocking Layer towards $\mathrm{Ce} 0.8 \mathrm{Sm}_{0.2} \mathrm{O}_{2-\delta}$-Based Solid Oxide Fuel Cells with High Open Circuit Voltages. Nano Energy 2014, 8, 305-311.

23. Zhao, J.; Xu, X.; Zhou, W.; Blakey, I.; Liu, S.; Zhu, Z., Proton-Conducting La-Doped Ceria-Based Internal Reforming Layer for Direct Methane Solid Oxide Fuel Cells. ACS Appl. Mater. Interfaces 2017, 9, 33758-33765.

24. Bi, L.; Da'as, E. H.; Shafi, S. P., Proton-Conducting Solid Oxide Fuel Cell (SOFC) with Y-Doped $\mathrm{BaZrO}_{3}$ Electrolyte. Electrochem. Commun. 2017, 80, 20-23.

25. Jaiswal, S. K.; Hong, J.; Yoon, K. J.; Son, J. W.; Lee, H.-W.; Lee, J. H., Optical Absorption and XPS Studies of $\left(\mathrm{Ba}_{1-\mathrm{x}} \mathrm{Sr}_{\mathrm{x}}\right)\left(\mathrm{Ce}_{0.75} \mathrm{Zr}_{0.10} \mathrm{Y}_{0.15}\right) \mathrm{O}_{3-\delta}$ Electrolytes for Protonic Ceramic Fuel Cells. Ceram. Int. 2016, 42, 10366-10372.

26. Scherban, T.; Villeneuve, R.; Abello,L.; Lucazeau, G., Raman Scattering Study of Phase Transitions in Undoped and Rare Earth Ion-Doped $\mathrm{BaCeO}_{3}$ and $\mathrm{SrCeO}_{3} . J$. Raman Spectrosc.1993, 24, 805-814. 
27. Machkova, M.; Brashkova,N.; Ivanov,P.; Carda, J. B.; Kozhukharov,V., Surface Behavior of Sr-Doped Lanthanide Perovskites. Appl. Surf. Sci.1997,119, 127-136.

28. Tabata, K., Effect of Thermal Treatments on the Catalytic Properties of La0.8 $\mathrm{Sr}_{0.2} \mathrm{CoO}_{3}$. J. Mater. Sci. Lett.1987, 6, 1030-1032.

29. Liu, B.; Zhang, Y.; Tang, L., X-ray Photoelectron Spectroscopic Studies of $\mathrm{Ba}_{0.5} \mathrm{Sr}_{0.5} \mathrm{Co}_{0.8} \mathrm{Fe}_{0.2} \mathrm{O}_{3-\delta}$ Cathode for Solid Oxide Fuel Cells. Int. J. Hydrogen Energ. 2009, 34, 435-439.

30. Huan, D.; Shi, N.; Zhang, L.; Tan, W.; Xie, Y.; Wang, W.; Xia, C.; Peng, R.; Lu, Y., A New Efficient and Reliable Air Electrode Material for Proton Conducting Reversible Solid Oxide Cells. ACS Appl. Mater. Interfaces 2018, 10, 1761-1770.

31. Meng, Q.; Wang, W.; Weng, X.; Liu, Y.; Wang, H.; Wu, Z., Active Oxygen Species in $\mathrm{La}_{n+1} \mathrm{Ni}_{n} \mathrm{O}_{3 n+1}$ Layered Perovskites for Catalytic Oxidation of Toluene and Methane. J. Phys. Chem. C 2016,120, 3259-3266.

32. Zhang, Z.; Zhu, Y.; Zhong, Y.; Zhou, W.; Shao, Z., Anion Doping: A New Strategy for Developing High-Performance Perovskite-Type Cathode Materials of Solid Oxide Fuel Cells. Adv. Energy Mater. 2017, 7, 1700242-1700250.

33. Amsif, M.; Marrero-Lopez, D.; Ruiz-Morales, J. C.; Savvin, S. N.; Gabás, M.; Nunez, P., Influence of Rare-Earth Doping on the Microstructure and Conductivity of $\mathrm{BaCe}_{0.9} \mathrm{Ln}_{0.1} \mathrm{O}_{3-\delta}$ Proton Conductors. J. Power Sources 2011, 196, 3461-3469. 


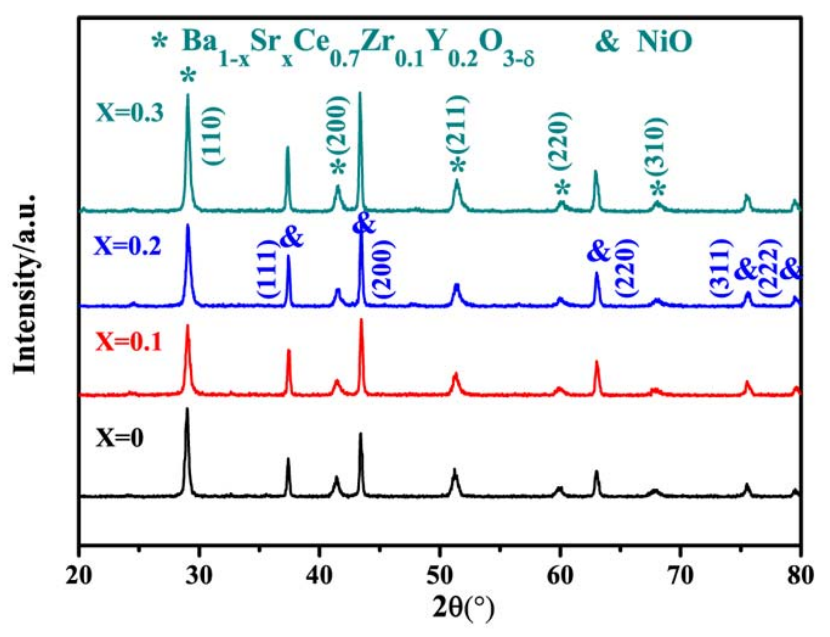

Figure 1 The XRD patterns of NiO-Ba1-x $\mathrm{Sr}_{\mathrm{x}} \mathrm{Ce}_{0.7} \mathrm{Zr}_{0.1} \mathrm{Y}_{0.2} \mathrm{O}_{3-\delta}(0 \leq \mathrm{x} \leq 0.3)$ composites calcined at $1000^{\circ} \mathrm{C}$ for $3 \mathrm{~h}$

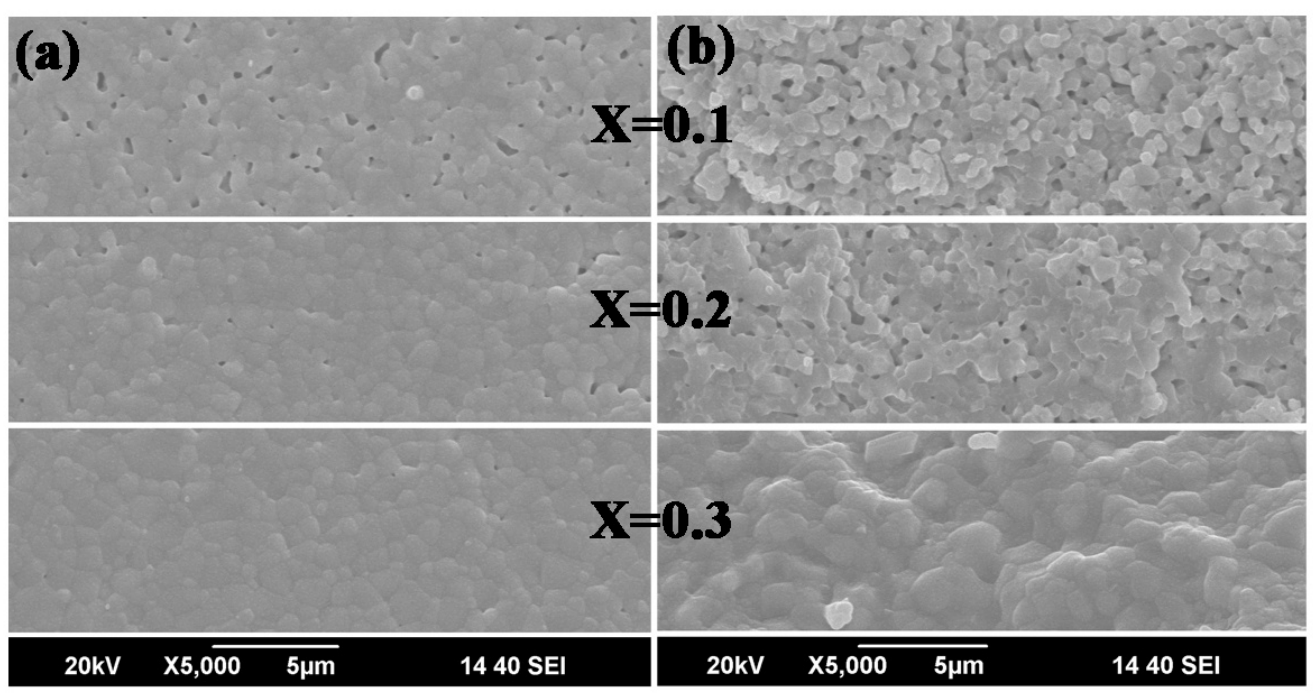

Figure 2 SEM images of the surface (a) and cross-sectional (b) morphology of SDC electrolyte in the NiO-Ba ${ }_{1-\mathrm{x}} \mathrm{Sr}_{\mathrm{x}} \mathrm{Ce}_{0.7} \mathrm{Zr}_{0.1} \mathrm{Y}_{0.2} \mathrm{O}_{3-\delta} / \mathrm{SDC}(0.1 \leq \mathrm{x} \leq 0.3)$ half cells sintered at $1150{ }^{\circ} \mathrm{C}$ for $5 \mathrm{~h}$. 


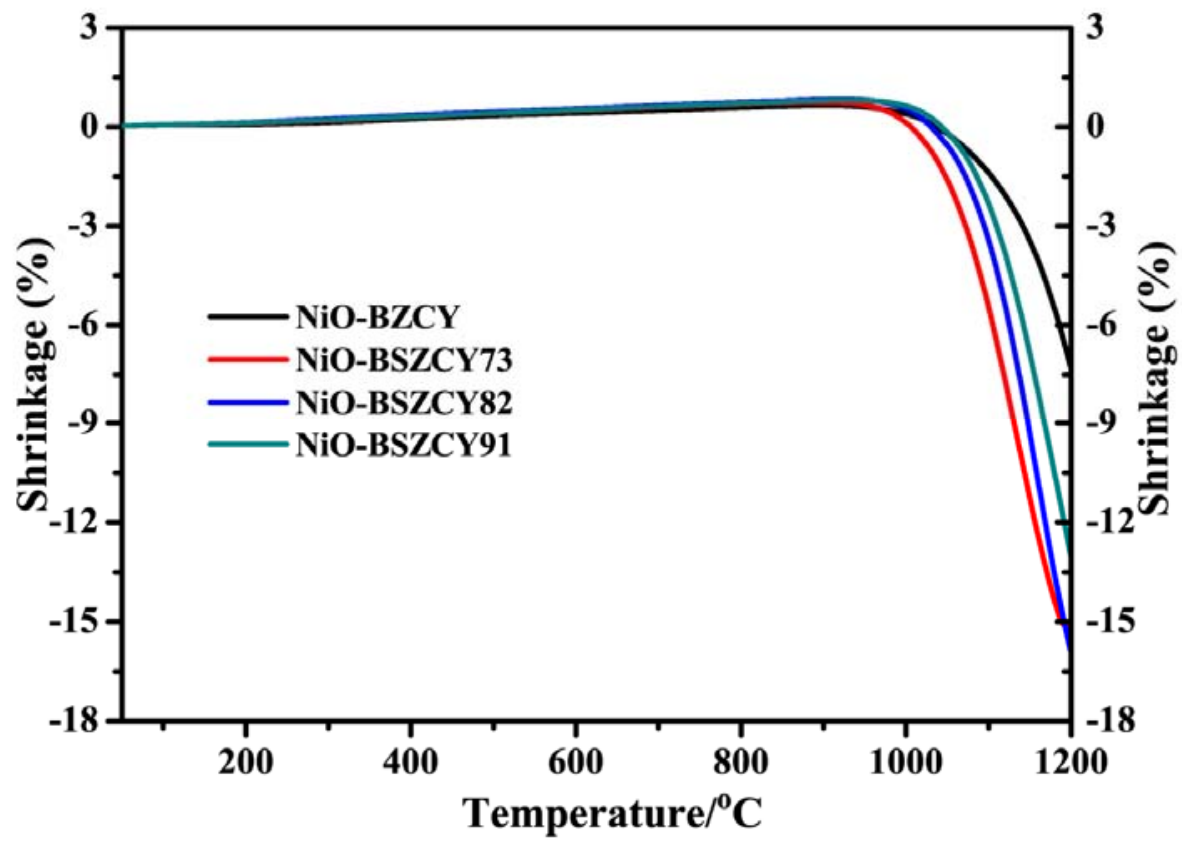

Figure 3 The shrinkage behaviors of NiO-Ba1-x $\mathrm{Sr}_{\mathrm{x}} \mathrm{Ce}_{0.7} \mathrm{Zr}_{0.1} \mathrm{Y}_{0.2} \mathrm{O}_{3-\delta}(0 \leq \mathrm{x} \leq 0.3)$ specimens
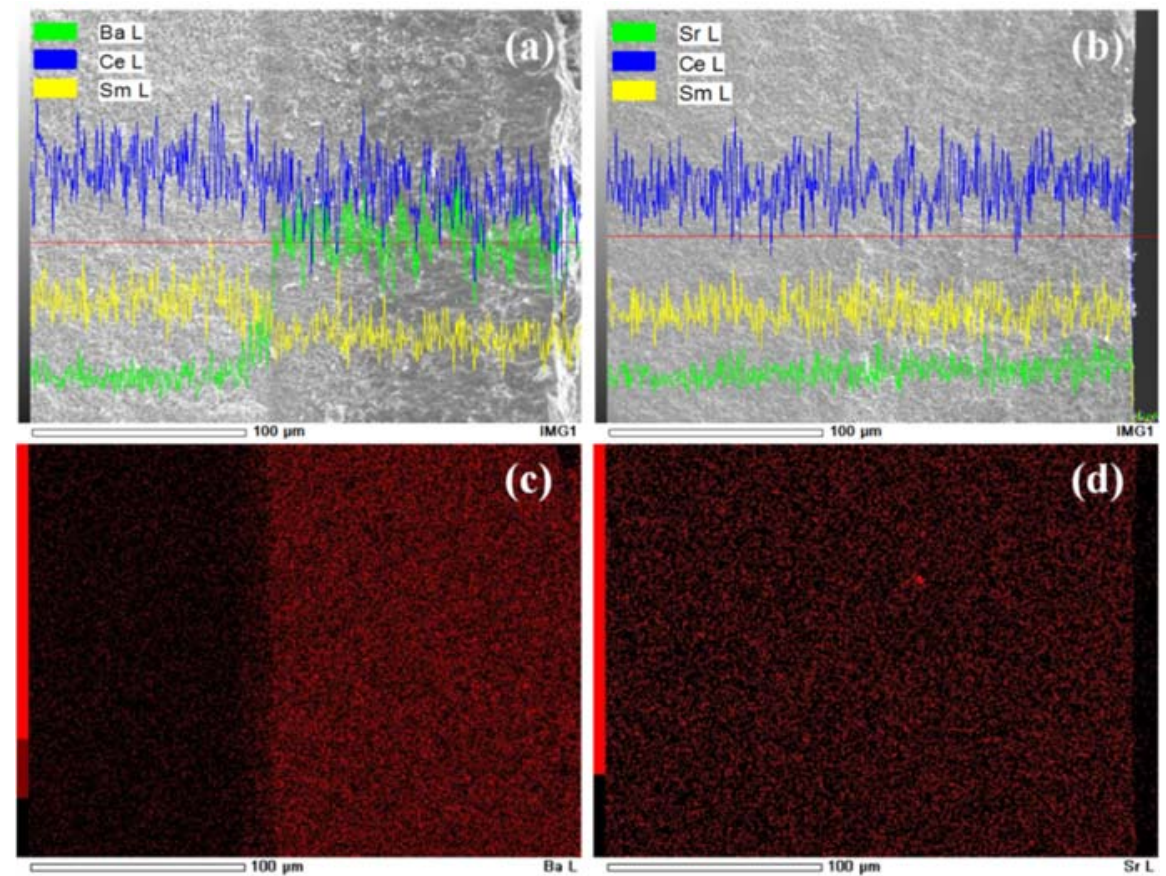

Figure 4 The SEM-EDS analysis in line-scan mode and element mapping results of the post-annealed SDC pellets closed to the coated $(a, c) \mathrm{BaCO}_{3}$ and $(b, d) \mathrm{SrCO}_{3}$ side. 


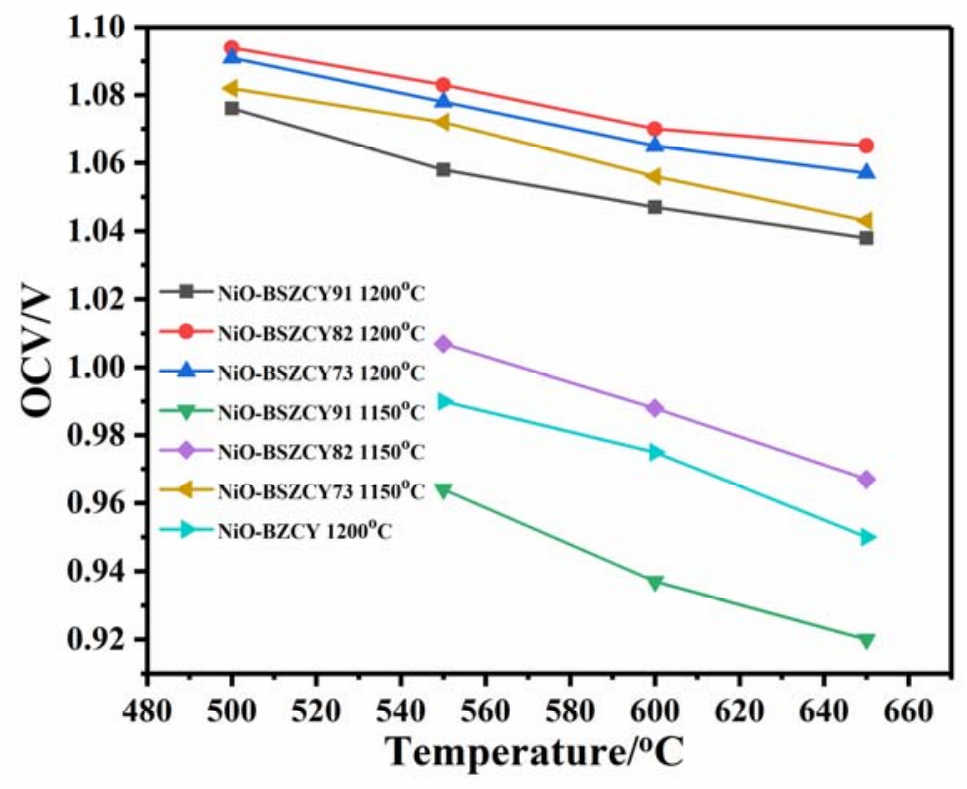

Figure 5 The temperature dependence of the OCV of the cells with different anodes sintered at 1200 or $1150{ }^{\circ} \mathrm{C}$
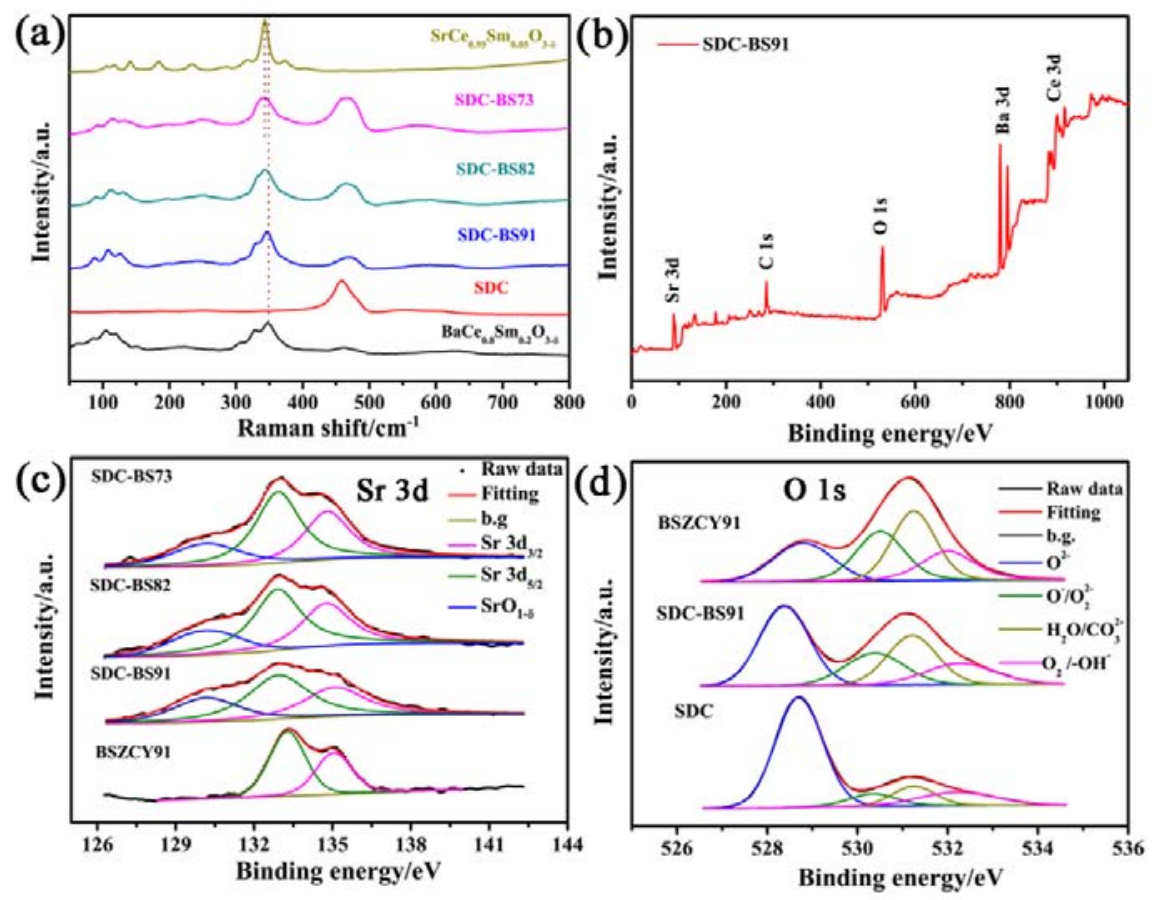

Figure 6 (a) The Raman spectra and (b) XPS full survey spectra of the SDC-BS91 powders, the survey spectra of (c) Sr 3d and (d) O 1s on the surface of the SDC, BSZCY91, SDC-BS91 powders. 

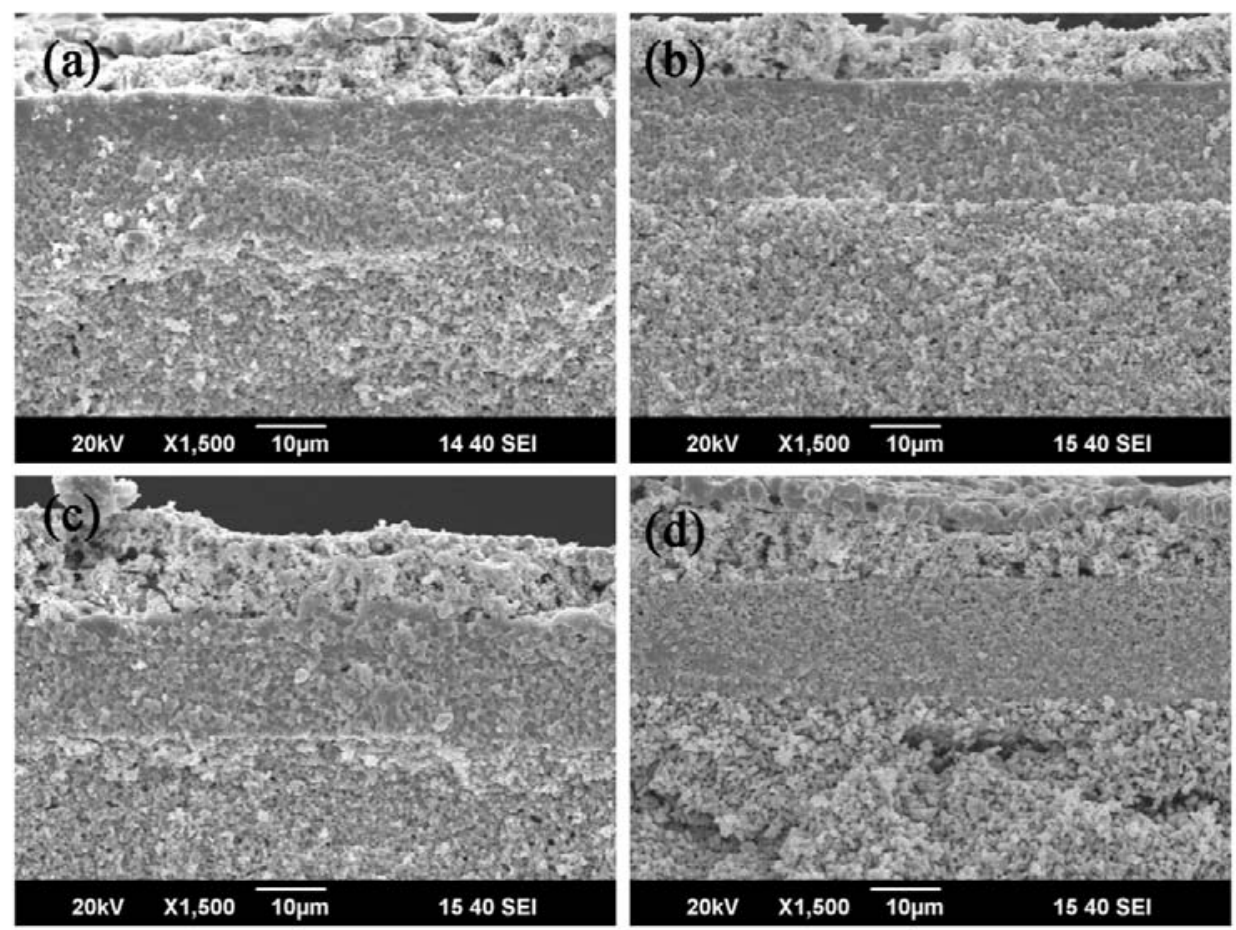

Figure 7 SEM images of the cross-section of the tested single cells with (a) NiO-BSZCY91, (b) NiO-BSZCY82, (c) NiO-BSZCY73, and (d) NiO-BZCY anodes.
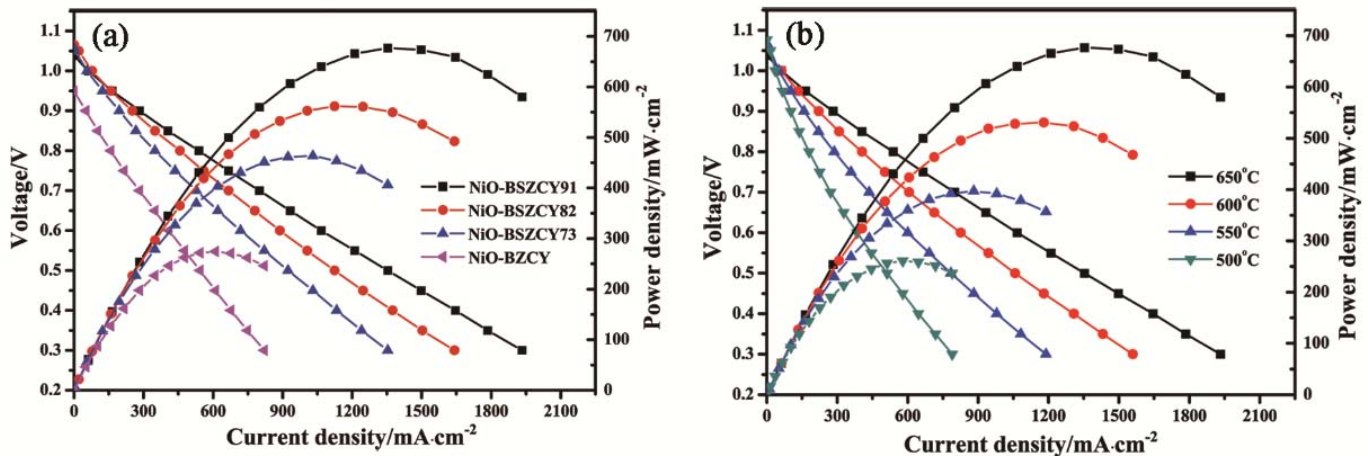

Figure 8The I-V and I-P curves of the single cells with (a) different anode at $650{ }^{\circ} \mathrm{C}$ and (b) NiO-BSZCY91 anode tested at different temperatures. 


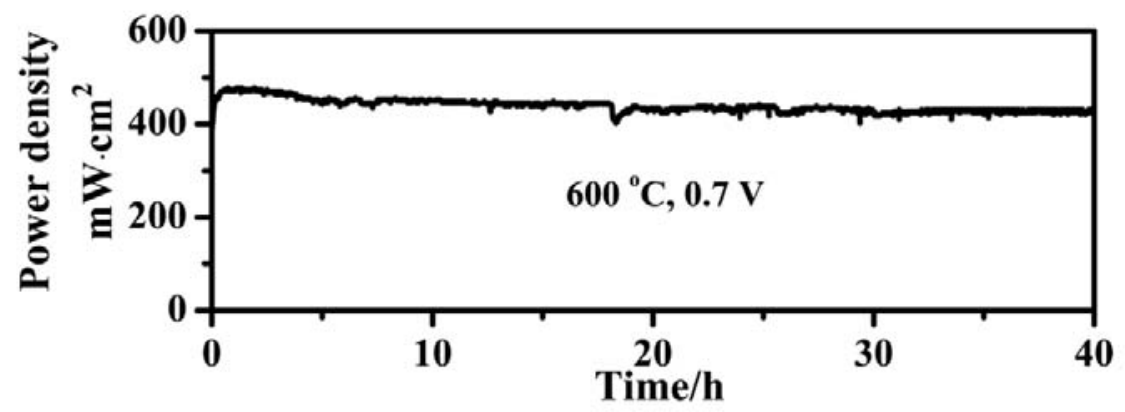

Figure 9 Power density as a function of time for the cell with optimal anode composition tested at $600{ }^{\circ} \mathrm{C}, 0.7 \mathrm{~V}$.

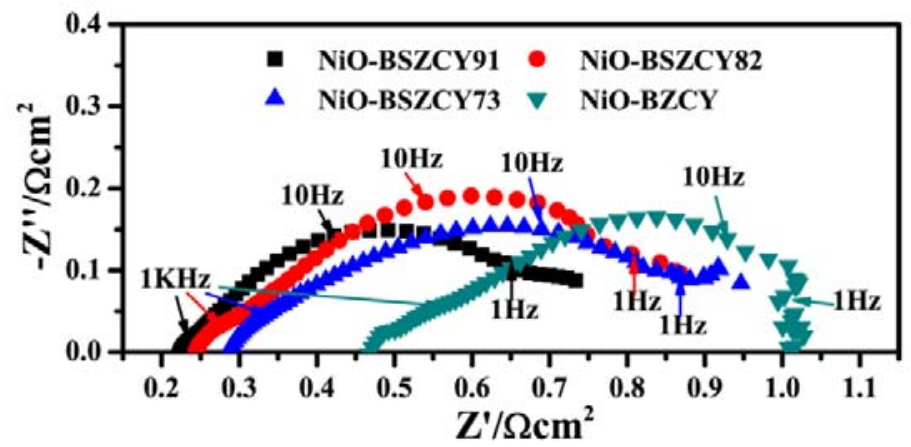

Figure 10 Electrochemical impedance spectra (EIS) of the cells with different anodes sintered at $1200{ }^{\circ} \mathrm{C}$ measured under open circuit conditions at $650{ }^{\circ} \mathrm{C}$ 
For Table of Contents Only

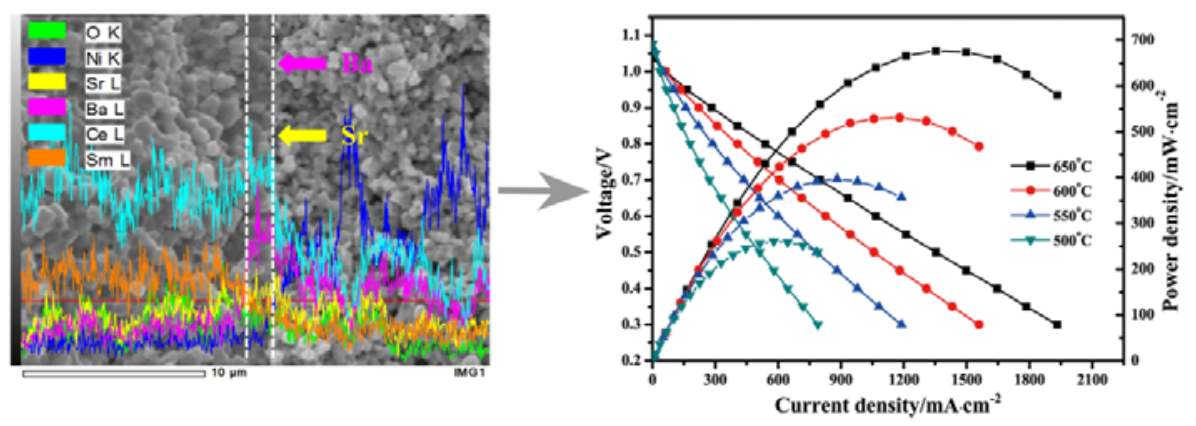

